
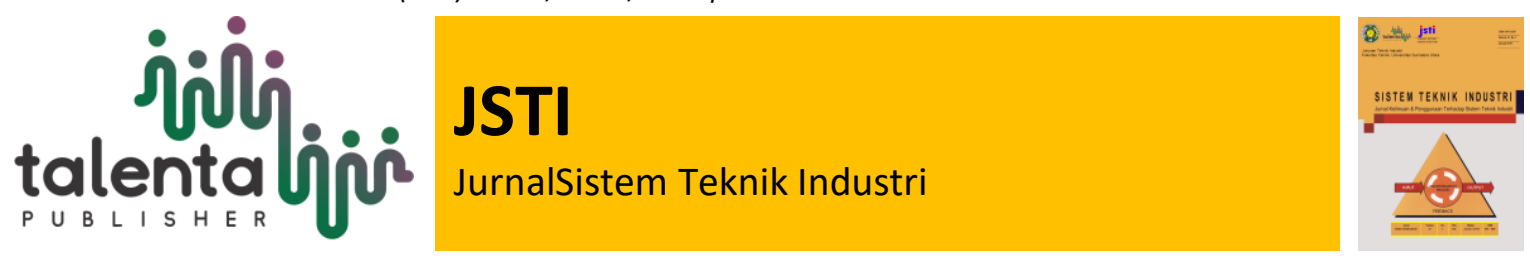

\title{
Performansi Alat Penukar Kalor Udara-Tanah Menggunakan Siklus Tertutup di Kota Medan
}

\author{
Terang UHS Ginting Manik ${ }^{a^{*}}$, Tulus Burhanuddin Sitorus ${ }^{a}$, Andi Syahputra \\ aDepartemen Teknik Mesin, Fakultas Teknik, Universitas Sumatera Utara
}

\begin{abstract}
Efforts to find alternative renewable energy sources lately are increasingly being intensified as increasing human demand for energy consumption is increasingly high. AirGround Heat Exchanger (EAHE) is one solution that can be developed by utilizing the energy stored in the soil. This research was conducted to determine the effect of EAHE performance on the decrease in air temperature that enters the test chamber as well as the exit, the Number of Transfer Unit and also the Coefficient of Performance value in the underground planting pipe. The results show that EAHE which is used as a passive cooling room can provide a pretty good performance by decreasing the temperature in the test room which reaches 3-6 $6^{\circ}$. The average NTU on June 18, 2019 was obtained at 1.238, and the highest was 1.254 with airspeed of $2 \mathrm{~m} / \mathrm{s}$. Meanwhile, on June 19, 2019, the highest NTU value was obtained at 1.134 and the average was 1.129 with an air speed of $3 \mathrm{~m} / \mathrm{s}$. When the air speed is $2 \mathrm{~m} / \mathrm{s}$, the COP value average was obtained at 0,258. When the air velocity is $3 \mathrm{~m} / \mathrm{s}$, the COP value average was obtained at 0,197.
\end{abstract}

Keywords: Earth-Air Heat Exchanger (EAHE); Number of Transfer Unit (NTU); Coefficient of Performance (COP)

\begin{abstract}
Abstrak. Upaya menemukan sumber energi alternatif terbarukan akhir-akhir ini semakin gencar dilakukan seiring meningkatnya kebutuhan manusia akan konsumsi energi yang semakin tinggi. Penukar Kalor Udara-Tanah atau Earth-Air Heat Exchanger (EAHE) merupakan salah satu solusi yang dapat dikembangkan dengan memanfaatkan energi yang tersimpan dalam tanah. Penelitian ini dilakukan untuk mengetahui pengaruh kinerja EAHE terhadap penurunan suhu udara yang masuk ke dalam ruangan uji maupun yang keluar, nilai Number of Transfer Unit dan juga nilai Coefficient of Performance pada pipa tanam bawah tanah. Hasil eksperimen menunjukkan bahwa EAHE yang digunakan sebagai pendingin pasif ruangan dapat memberikan kinerja yang cukup baik dengan penurunan suhu di ruangan uji yang mencapai $3-6^{\circ}$ C. NTU rata-rata pada tanggal 18 Juni 2019 diperoleh sebesar 1.238, dan tertinggi sebesar 1.254 dengan kecepatan udara $2 \mathrm{~m} / \mathrm{s}$. Sementara itu, pada tanggal 19 Juni 2019, di peroleh nilai NTU tertinggi sebesar 1.134 dan rata-rata sebesar 1.129 dengan kecepatan udara $3 \mathrm{~m} / \mathrm{s}$. Saat kecepatan udara $2 \mathrm{~m} / \mathrm{s}$, nilai COP rata-rata didapatkan 0,258. Ketika kecepatan udara $3 \mathrm{~m} / \mathrm{s}$, nilai COP rata-rata didapatkan 0,197.
\end{abstract}

Kata Kunci: Penukar Kalor Udara-Tanah (Earth-Air Heat Exchanger (EAHE)); Number of Transfer Unit (NTU); Coefficient of Performance (COP)

Received 10 Januari 2020 | Revised 25 Januari 2020 | Accepted 25 Januari 2020

*Corresponding author at: Universitas Sumatera Utara, Medan, 20155, Indonesia

E-mail address: terang1@usu.ac.id

Copyright (C 2020 Published by Talenta Publisher, ISSN: 1411-5247 e-ISSN: 2527-9408

Journal Homepage: http://talenta.usu.ac.id/jsti 


\section{Pendahuluan}

Manusia selalu membutuhkan kondisi lingkungan yang nyaman dalam sebuah bangunan .Namun, energi sangat dibutuhakan untuk menjaga kondisi lingkungan dalam bangunan yang nyaman.Saat ini, konsumsi energy untuk bangunan mencapai $25-40 \%$ dari total konsumsi energy dunia, dimana sebagian besar energy dihabiskan untuk memanaskan ataupun mengkondisikan udara dan berasal dari bahan bakar fosil seperti batubara, minyak dan gas bumi. Kebutuhan untuk pengembangan yang berkelanjutan mendorong manusia untuk mencari alternatif, energi terbarukan untuk mengkondisikan lingkungan dalam sebuah bangunan [1].

Akibat meningkatnya kebutuhan manusia akan udara yang nyaman, meningkatnya harga energy dan masalah lingkungan orang berlomba-lomba untuk menemukan sebuah system berbasis energy terbarukan yang mampu menjawab semua tantangan tersebut. Salah satu solusi yang dapat dikembangkan adalah memanfaatkan energi yang tersimpan dalam tanah (earth energy).Energi ini dapat dimanfaatkan sebagai ventilasi maupun sistem pengkondisian udara dengan menggunakan alat yang disebut penukar kalor antara udara-tanah atau EAHE (Earth-Air Heat Exchanger) [1].

Tanah menerima radiasi surya melalu permukaannya dan berperan sebagai sebuah reservoir energy surya yang besar. Karena inersia panas dari tanah, fluktuasi dari amplitude temperatur tanah meningkat secara eksponensial seiring dengan pertambahan kedalaman. Karena itu, pada kedalaman yang cukup, tanah tidak sedingin udara luar pada musim dingin dan tidak sepanas udara luar pada musim panas.Hal ini merupakan sebuah kesempatan yang menjanjikan untuk menggunakan energi geothermal pada pendinginan ataupun pemanasan pasif pada kondisi udara dalam bangunan.

Sebuah alat penukar kalor dara tanah terdiri dari satu atau lebih pipa yang diletakkan dibawah tanah untuk mensuplai pengkondisian udara pada bangunan.Fenoma yang terjadi cukup sederhana dan bergantung padaperbedaan temperature antara tanah dengan udara lingkungan. Udara lingkungan dialirkan kedalam pipa yang ditanam di bawah tanah menggunakan blower dan mengalami perpindahan panas langsung dengan tanah dan udara tersebut bersirkulasi di dalam ruangan uji. Upaya pengembangan metode sistem perpindahan panas pada lapisan tanah ini selain untuk pendinginan ruangan yang berbiaya murah juga diharapkan dapat memperbaiki lingkungan dengan mengurangi kadar CFC (Chloro-Fluoro-Carbon) dalam udara yang banyak digunakan mesin-mesin pendingin ruangan seperti AC (air conditioner). Penelitian ini dilakukan untuk mengetahui nilai NTU dan $\varepsilon$ dari $E A H E$, termasuk pengaruh kinerja $E A H E$ terhadap penurunan suhu udara masuk serta untuk mengetahui suhu udara yang masuk ke dalam ruangan uji ( $T_{\text {out }}$ EAHE).

Sebagai tambahan, penelitian ini juga dilakukan untuk mengetahui nilai COP (Coefisient of 
Performance) pada pipa tanam bawah tanah. Melalui penelitian ini, hasil yang akan dicapai adalah membuat pendingin ruangan alami yang dapat dimaksimakan dengan energi terbarukan, diketahui suhu ruangan optimal dan besar penurunan temperatur yang diperoleh dari alat penukar kalor udara tanah.

Dalam analisis alat penukar kalor, dikenal koefisien perpindahan panas menyeluruh (Overall Heat Transfer Coefficient) yang memperhitungkan semua efek yang terjadi pada perpindahan panas [4]. Besarnya laju perpindahan panas ini bisa berbeda-beda pada sepanjang titik alat penukar kalor. Dalam analisa alat penukar kalor, metode yang paling mudah digunakan adalah metode LMTD (Log Mean Temperature Difference) yang berarti nilai tengah perbedaan temperatur di sepanjang alat penukar kalor, Namun, bila temperatur pada sisi keluar alat penukar kalor tidak diketahui, untuk menganalisa alat penukar kalor digunakan metode keefektifan - NTU [3].

Alat penukar kalor bawah tanah atau sering disebut EAHE merupakan alat penukar kalor dengan pengaplikasian satu pipa atau lebih yang dipendamkan di dalam tanah dengan kedalaman tertentu. Pipa yang digunakan adalah pipa dari bahan PVC (polyvnyl chloride), HDPE (high density polyrthylene) maupun pipa galvanis. Dalam melakukan siklus alat penukar kalor, Earth Air Heat Exchanger memiliki 2 macam siklus kerja yang berbeda. Perbedaan siklus tersebut adalah keluaran udara akhir, apakah akan dialirkan kembali masuk kedalam EAHE atau dilepaskan keudara. Siklus tersebut terbagi atas siklus terbuka (Open Loop) dan siklus tertutup (Close Loop) [1].

Penggunaan tanah sebagai media perpindahan panas juga sangat berpengaruh, dalam menerapkan EAHE. Penggungaan tanah basah tentunya akan lebih baik dalam menghantarkan panas daripada tanah kering. Dalam penerapan EAHE dengan konveksi paksa (adanya penambahan blower) udara keluar akan sangat bergantung dari kecepatan blower itu sendiri. Sebaliknya. apabila dengan menerapkan konveksi alamiah (tanpa blower) maka udara yang dihantarkan akan memanfaatkan perbedaan tekanan dari input dan output Alat Penukar Kalor Udara Tanah itu sendiri. Material pipa yang digunakan sebagai media penhantar juga perlu diperhatikan. Penggunaan pipa dengan nilai konduktivitas yang sesuai dengan konduktivitas tanah akan sangat mendukung performansi dari Alat Penukar Kalor Udara Tanah.. Selain itu juga, kedalaman tanah juga menjadi faktor pendukung, karena semakin dalam pipa EAHE ditempatkan maka gradien temperautr akan meningkat. Untuk pengaplikasiannya kedalaman $2 \mathrm{~m}$ hingga $3 \mathrm{~m}$ sudah sangat baik untuk meningkatkan gradien suhu yang tinggi [1].

Pada penelitian ini, tipe aliran yang digunakan adalah single stream. Besarnya nilai perpindahan panas dari alat penukar kalor udara-tanah dapat ditentukan dari persamaan [4]:

$\mathrm{Qh}=\dot{\mathrm{m} C p}\left(T_{\text {out }}-\mathrm{T}_{\text {in }}\right)$ 
di mana $\mathrm{Cp}$ adalah nilai panas spesifik dari udara $(\mathrm{J} / \mathrm{kg}-\mathrm{k})$, m adalah laju aliran massa $(\mathrm{kg} / \mathrm{s})$ dan Tout adalah temperatur sisi keluar pipa, Tin adalah temperatur sisi masuk pipa. Sedangkan untuk menentukan besar konveksi aliran pada udara dengan dinding pipa dapat digunakan persamaan (1), dengan perbedaan pada $\Delta T$ yang digunakan adalah perbedaan temperatur rata-rata $\Delta T_{l m}$ yaitu [5] :

$\Delta T=\frac{T_{\text {in }}-T_{\text {out }}}{\ln \left[\frac{T_{\text {in }}-T_{\text {wall }}}{T_{\text {out }}-T_{\text {wall }}}\right]}$

di mana :

$\mathrm{T}_{\text {wall }}=\operatorname{suhu}$ tanah $\left(\mathrm{T}_{\text {soil }}\right)$

Untuk resistansi termal pipa dapat digunakan dengan persamaan [6] :

$$
\begin{aligned}
& R_{\text {soil }}=\frac{1}{K_{\text {pipe } 2 \pi L}} \ln \left(r_{e} / r_{i}\right) \\
& \text { Kpipe }=\text { konduktivitas termal } \operatorname{PVC~}(0,52 \mathrm{~W} / \mathrm{mK}) \\
& \text { re } \quad=\text { jari-jari bagian luar pipa }(\mathrm{m})
\end{aligned}
$$

Sementara nilai resistansi termal untuk tanah ditentukan dengan persamaan :

$R_{\text {soil }}=\frac{1}{K_{\text {pipe }} 2 \pi L} \ln \left(R(z, x) \mid r_{e}\right)$

dimana :

$\mathrm{K}_{\text {soil }}=$ konduktivitas termal tanah $(0,16 \mathrm{~W} / \mathrm{mK})$

$\mathrm{R}(\mathrm{z}, \mathrm{x})=$ kedalaman tanah $(\mathrm{m})$

Dan nilai resistansi termal antara dinding bagian dalam pipa dengan udara ditentukan melalui persamaan :

$R_{\text {conv }}=\frac{1}{h A_{i}}$

Sehingga untuk menghitung konduktivitas termal untuk sebuah alat penukar kalor Alat Penukar Kalor Udara Tanah dapat digunakan [6] :

$U=\frac{1}{\left(R_{\text {conv }}+R_{\text {pipe }}+R_{\text {soil }}\right)}$

di mana:

Rconv : Tahanan konveksi

Rpipe : Tahanan Pipa

$R_{\text {soil }}:$ Tahanan Tanah

Dalam model ini, $R_{\text {tot }}$ terdiri dari resistansi konveksi di dalam pipa $\left(R_{C o n v}\right)$, resistansi konduksi 
dinding pipa (Rpipe), dan resistansi konduksi tanah ( $\left.R_{\text {Soil }}\right)$. Denga demikian Rtot disajikan dengan persamaan [6] :

$R_{\text {tot }}=\left(R_{\text {conv }}+R_{\text {pipe }}+R_{\text {soil }}\right)$

Jika dimensi pipa memiliki panjang yang tak terhingga $(\mathrm{A}=\infty)$, maka udara akan didinginkan serupa dengan temperatur dinding dalam pipa. Maka nilai dari NTU alat penukar kalor udaratanah dapat ditentukan dari persamaan [7]:

$$
N T U=\frac{U A}{\dot{\mathrm{m}} \mathrm{p}}
$$

dimana m adalah laju aliran massa $(\mathrm{kg} / \mathrm{s}), \mathrm{U}$ adalah koefisien perpindahan panas $\left(\mathrm{Wm}^{2 / K}\right)$, dan cp adalah nilai panas spesifik dari udara (J/kg-k). Nilai efektivitas alat penukar kalor udaratanah teoritis didapat dari korelasi [7]:

$$
\varepsilon=1-e^{-N T U}
$$

Untuk menentukan efektivitas alat penukarkalor hasil eksperimental diperoleh dari persamaan [7]:

$$
\varepsilon=\frac{T_{\text {in }}-T_{\text {out }}}{T_{\text {in }}-T_{\text {soil }}}=1-e^{-(h A / \dot{m} \mathrm{C})}
$$

dengan mensubstitusikan nilai untuk temperatur udara masuk dan temperatur udara keluar eksperimental serta temperatur tanah. Nilai dari koefisien performansi dari alat penukar kalor udara-tanah dapat ditentukan dari persamaan [9]:

$$
C O P=\frac{Q_{c}}{P_{f}}
$$

di mana Pf adalah energi yang diperlukan untuk menggerakkan blower pada penukar panas udaratanah. Besarnya kapasitas pendinginan yang terjadi diperoleh dari persamaan:

$$
\mathrm{Q}_{\mathrm{c}}=\dot{\mathrm{m} C \mathrm{p}}\left(T_{\text {in }}-T_{\text {out }}\right)
$$

\section{Material dan Metode Penelitian}

Alat penukar kalor udara-tanah yang dirakit menggunakan pipa PVC dengan diameter 10,16 $\mathrm{mm}$ dan ketebalan $3 \mathrm{~mm}$. Untuk mensirkulasikan udara digunakan blower yang diatur putarannya menggunakan inverter. Termokopel tipe $\mathrm{K}$ dengan akurasi $\square 0.1^{\circ} \mathrm{C}$ diletakkan pada sisi masuk dan sisi keluar serta pada beberapa titik sepanjang alat penukar kalor. Disamping itu termokopel diletakkan juga pada kedalaman $2 \mathrm{~m}$ di bawah permukaan tanah. Objek penelitian adalah udara lingkungan yang disirkulasikan ke dalam alat penukar kalor udara-tanah untuk 
didinginkan.

Tabel 1 Spesifikasi alat penukar kalor udara-tanah

\begin{tabular}{lll}
\hline No & \multicolumn{1}{c}{ Data } & \multicolumn{1}{c}{ Keterangan } \\
\hline 1 & Diameter pipa EAHE & $\mathrm{d}=0,1016 \mathrm{~m}$ \\
2 & Panjang pipa EAHE & $\mathrm{L}=26,5 \mathrm{~m}$ \\
3 & Kedalaman tanah & $\mathrm{Z}=2 \mathrm{~m}$ \\
4 & Media yang didinginkan & Udara \\
5 & Jumlah blower & $1 \quad$ buah @ 2850 rpm \\
\hline
\end{tabular}

Diagram alur penelitian dari proses pengambilan data hingga perhitungan nanti dapat dilihat pada Gambar 1. Secara garis besar dimulai dari Identifikasi masalah dan tujuan dari penelitian, pengumpulan data dari data lingkungan, radiasi matahari dan profil dari PVC yang digunakan.Selanjutnya akan dimulai proses pengumpulan data-data yang diperlukan dalam perhitungan dan analisis serta akan berakhir diperbandingan apakah systemEarth Air Heat Exchanger dapat bekerja maksimal sesuai dengan potensi yang diharapkan. Berikut dapat dilihat diagram alir dari penelitian yang dilakukan. 


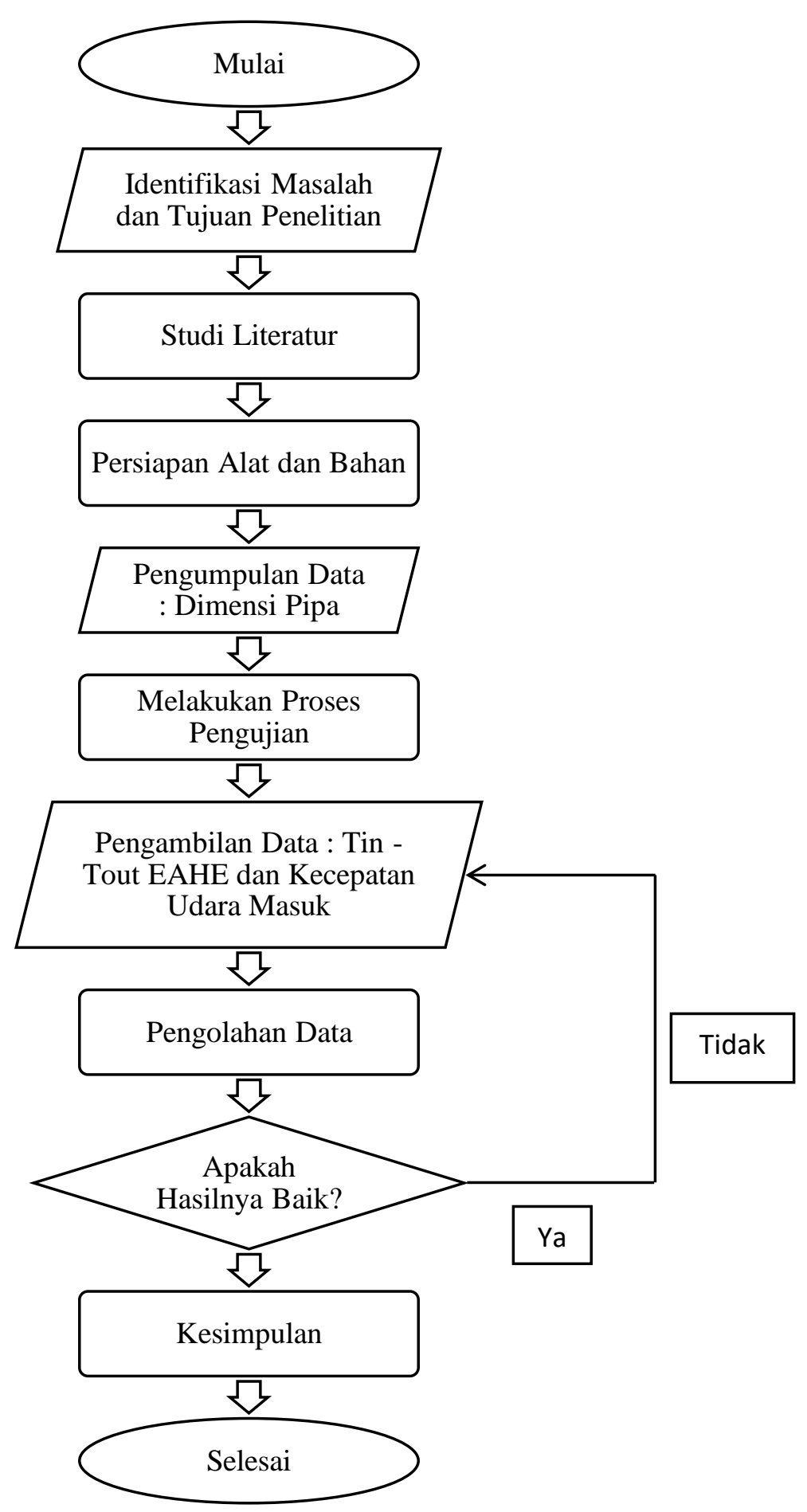

Gambar 1 Diagram Alir Penelitian

Proses pengujian dilakukan mulai dari pukul 10.00 WIB pagi dimana blower mulai mensirkulasikan udara ke dalam alat penukar kalor udara-tanah. Data akuisisi yang terhubung ke termokopel merekam temperatur pada sisi masuk dan sisi keluar sepanjang pipa alat penukar kalor udara-tanah serta temperatur tanah setiap menit. Untuk menghasilkan kecepatan udara masuk yang sesuai digunakan inverter motor listrik tiga fasa. Proses pengujian diakhiri pada pukul 18.00 WIB. Kemudian pengujian dilakukan keesokan harinya dengan prosedur yang sama. Tabel 1 menampilkan spesifikasi dari sistem alat penukar kalor udara-tanah yang diuji. 


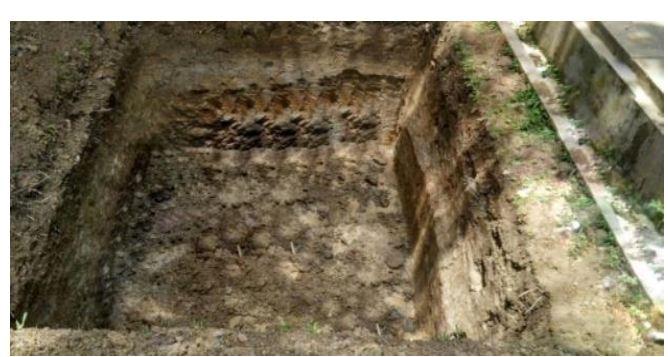

(a)

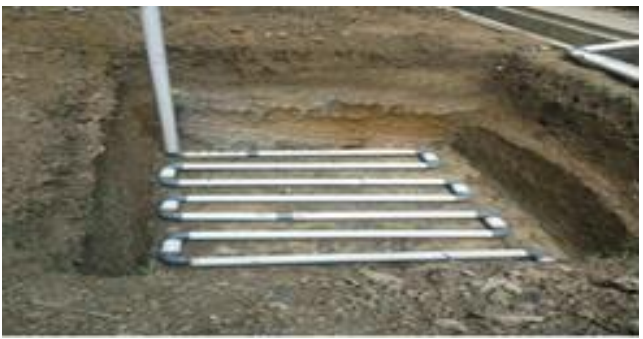

(b)

Gambar 2. (a) Lokasi dan (b) alat penukar kalor udara-tanah yang dirakit

Gambar 1 di atas menampilkan lokasi dan alat penukar kalor udara-tanah yang dirakit. Sementara itu, Gambar 2 menunjukkan skema eksperimental saat pengujian. Udara dialirkan ke dalam pipa menggunakan blower dengan kecepatan aliran udara masuk $2 \mathrm{~m} / \mathrm{s}$ dan $3 \mathrm{~m} / \mathrm{s}$. Blower dihubungkan dengan inverter sehingga dapat diatur frekuensi putaran blower untuk menghasilkan kecepatan aliran udara yang diinginkan. Untuk mengetahui kecepatan udara yang dihasilkan maka digunakan alat ukur anemometer.

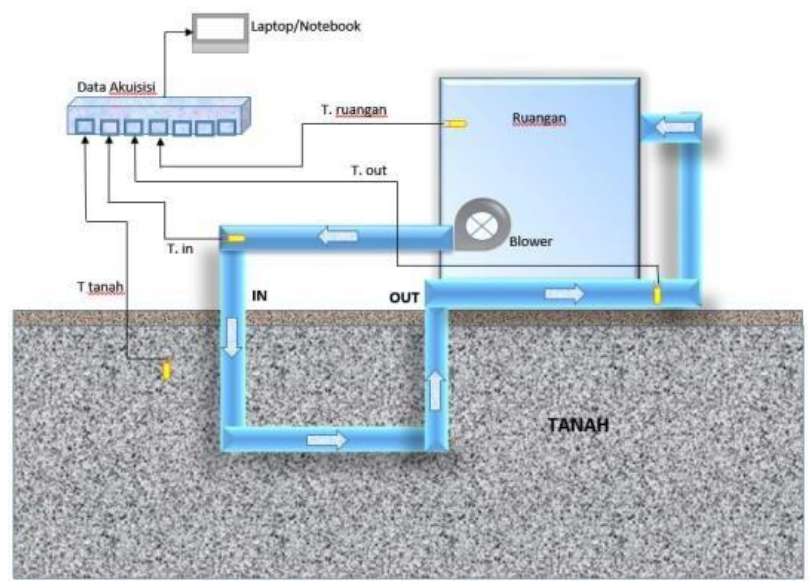

Gambar 3. Skema eksperimental

Adapun Tujuan dari dilakukannya penelitian ini yaitu untuk mengetahui pengaruh kinerja $E A H E$ terhadap penurunan suhu udara masuk $\left(T_{\text {in-EAHE }}\right)$ dengan menghitung nilai dari NTU dan COP yang dihasilkan oleh EAHE.

\section{Hasil dan Diskusi}

Gambar 3 menampilkan kondisi temperatur keluaran udara teoritis untuk kecepatan udara $2 \mathrm{~m} / \mathrm{s}$ pada pengujian pada tanggal 18 Juni 2019. Diperoleh temperatur masukan rata-rata sebesar $35.25^{\circ} \mathrm{C}$ dan temperatur keluaran rata-rata sebesar $33.36^{\circ} \mathrm{C}$. Berdasarkan data hasil pengukuran 
diperoleh bahwa alat penukar kalor udara-tanah mampu menurunkan temperatur udara rata-rata sebesar $1.89^{\circ} \mathrm{C}$.

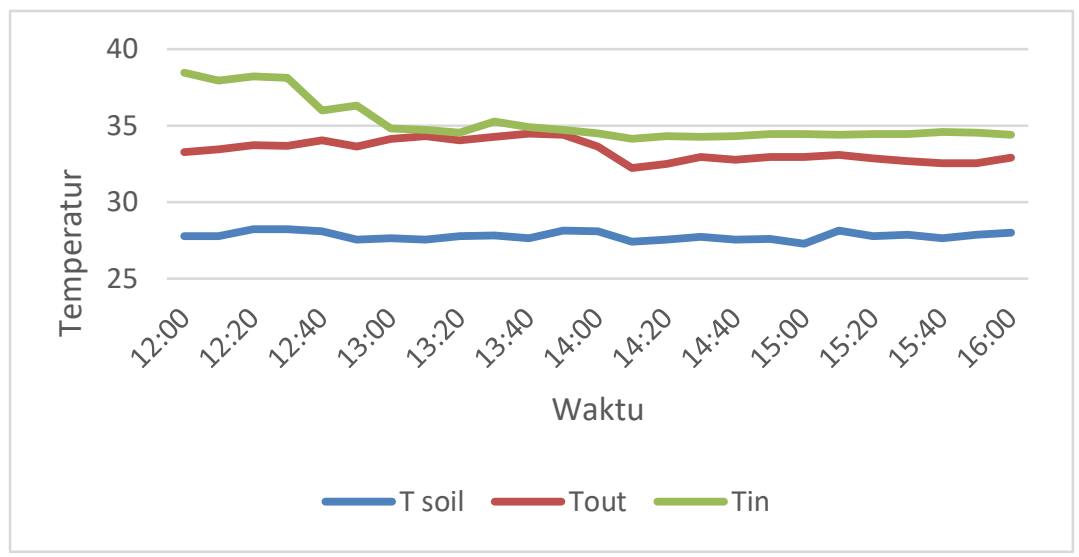

Gambar 3. Kondisi temperatur yang diamati pada 18 Juni 2019

Sementara itu, Gambar 4 menampilkan temperatur keluaran teoritis untuk kecepatan udara 3 $\mathrm{m} / \mathrm{s}$ yang dilakukan pada pengujian pada tanggal 19 Juni 2019. Diperoleh temperatur masukan rata-rata sebesar $31.03^{\circ} \mathrm{C}$ dan temperatur keluaran rata-rata sebesar $29.62^{\circ} \mathrm{C}$. Berdasarkan data hasil pengukuran diperoleh bahwa alat penukar kalor udara-tanah mampu menurunkan temperatur udara rata-rata sebesar $1.41^{\circ} \mathrm{C}$.

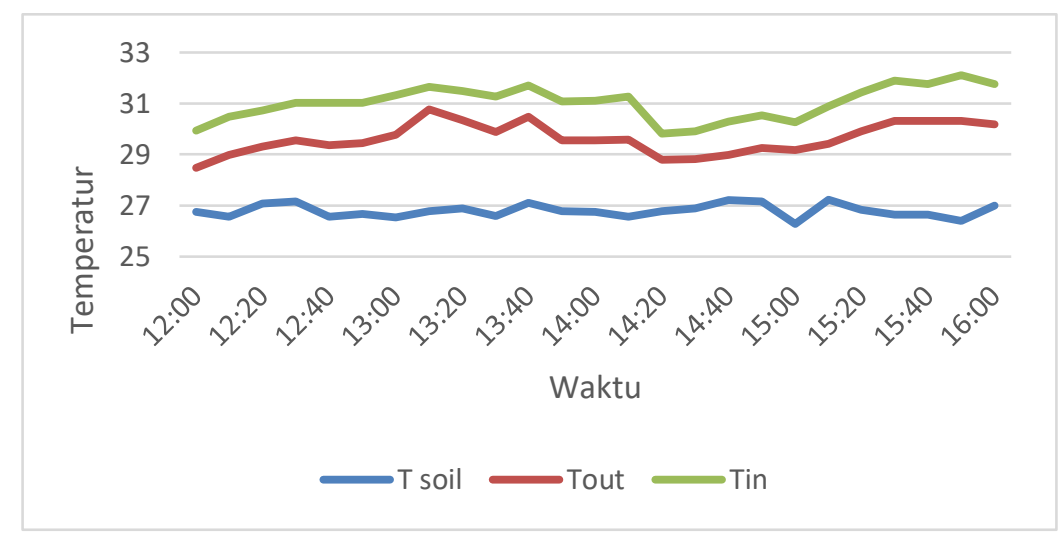

Gambar 4. Kondisi Temeratur yang diamati 19 Juni 2019

Setelah dilakukan perhitungan data eksperimental berdasarkan data yang didapat pada tanggal 18 Juni 2019, maka diperoleh kondisi temperatur masuk dan keluar terlihat pada Gambar 5, sebagai berikut: 


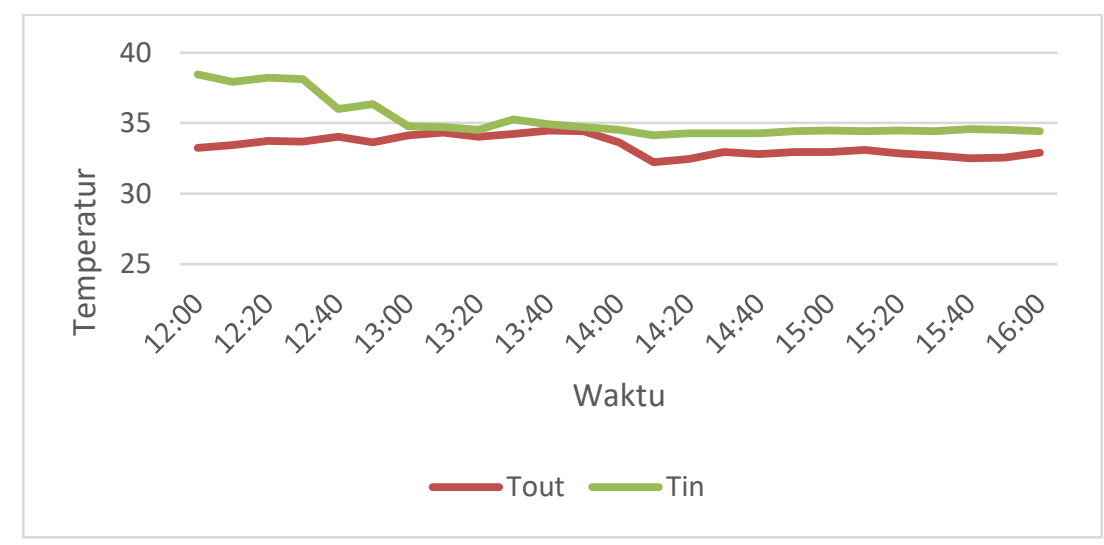

Gambar 5. Kondisi temperatur masuk dan temperatur keluar Tanggal 18 Juni 2019

Gambar 5 menunjukkan besar penurunan suhu yang terjadi selama pengujian pada tanggal 18 Juni 2019. Suhu maksimal masuk ke dalam EAHE ( $\mathrm{T}_{\text {in-EAHE}}$ ) sebesar $38.46^{\circ} \mathrm{C}$ dan suhu terendah masuk ke dalam EAHE sebesar $34.14^{\circ} \mathrm{C}$. Suhu keluar EAHE ( $\left.\mathrm{T}_{\text {out-EAHE}}\right)$ maksimal sebesar $32.23^{\circ} \mathrm{C}$ dan suhu terendah keluar EAHE sebesar $34.48^{\circ} \mathrm{C}$. Penurunan suhu yang dapat dikerjakan oleh Earth Air Heat Exchanger rata-rata sebesar 2-4 ${ }^{\circ} \mathrm{C}$. Hal yang paling berpengaruh selama pengujian adalah kecepatan udara yang masuk kedalam EAHE. Kecepatan udara rata-rata berada pada kecepatan $2 \mathrm{~m} / \mathrm{s}$ dengan aliran massa yang dihasilkan sebesar 0,0185 kg/s.

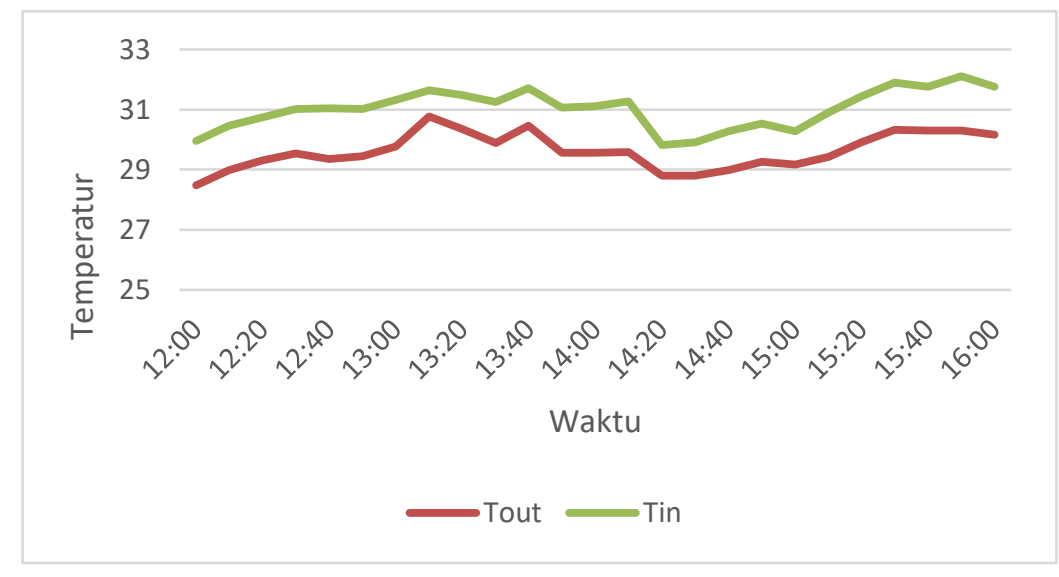

Gambar 6 Kondisi temperatur masuk dan temperatur keluar Tanggal 19 Juni 2019

Gambar 6 menunjukkan perhitungan data eksperimental berdasarkan data pada 19 Juni 2019. Dapat dilihat bahwa terdapat perbedaan suhu yang masuk dan keluar dengan rata - rata perbedaan suhu $2^{\circ} \mathrm{C}$ dengan suhu pada ruangan lebih rendah dari suhu lingkungan sekitar ruangan.

\subsection{Koefisien Performansi}

Dari data eksperimen dan hasil pengujian maka diperoleh nilai COP alat penukar kalor udaratanah seperti tampak pada Tabel 2:

Tabel 2 Coefficient of Performance 


\begin{tabular}{cll}
\hline $\mathbf{V}_{\text {in }}(\mathbf{m} / \mathbf{s})$ & \multicolumn{1}{c}{ Kondisi } & COP \\
\hline \multirow{2}{*}{2} & Maksimum & 0,707 \\
& Rata-rata & 0,258 \\
\multirow{2}{*}{3} & Maksimum & 0,251 \\
& Rata-Rata & 0,197 \\
\hline
\end{tabular}

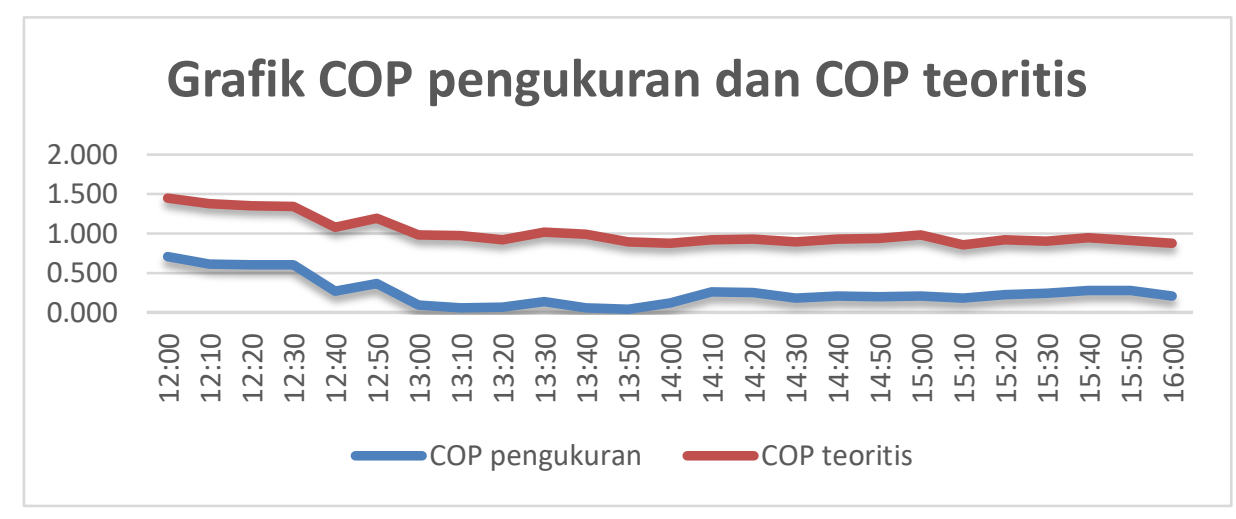

Gambar 7 Hasil COP pengukuran dan COP teoritis Tanggal 18 Juni 2019

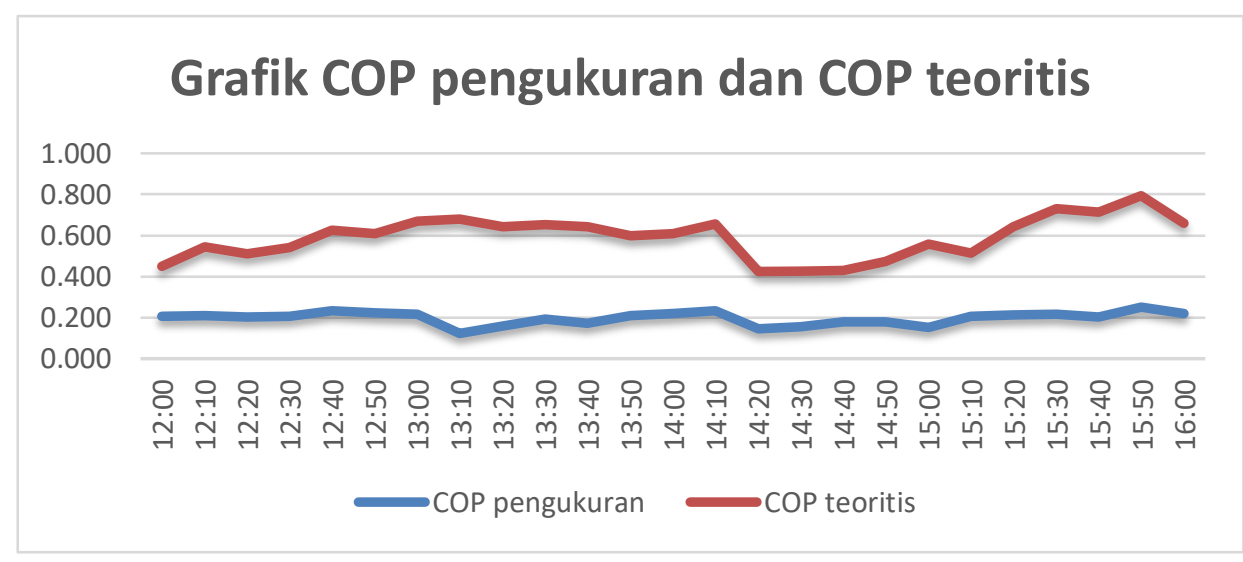

Gambar 8 Hasil COP pengukuran dan COP teoritis Tanggal 19 Juni 2019

Dari Gambar 7 dan 8 dan Tabel 1 dapat dilihat bahwa dengan kecepatan udara masuk (V udara) $2 \mathrm{~m} / \mathrm{s}$, nilai COP alat penukar kalor yang didapat adalah 0,707 dengan rata-rata COP adalah 0,258. Nilai maksimum COP didapat dengan kecepatan udara masuk $3 \mathrm{~m} / \mathrm{s}$ sebesar 0,251 dengan ratarata 0,197 .

\subsection{Number of Transfer Unit}

Yang diperoleh dari hasil pengujian ditampilkan pada Tabel 3. 
Tabel 3 Nilai NTU EAHE

\begin{tabular}{cll}
\hline $\mathbf{V}_{\text {in }}(\mathbf{m} / \mathbf{s})$ & \multicolumn{1}{c}{ Kondisi } & NTU \\
\hline 2 & Maksimum & 1,254 \\
& Rata-rata & 1,238 \\
3 & Maksimum & 1,134 \\
& Rata-Rata & 1,129 \\
\hline
\end{tabular}

Berdasarkan nilai NTU yang diperoleh maka dapat ditentukan nilai efektifitas dari EAHE seperti tampak pada Tabel 4:

Tabel 4 Nilai Efektivitas EAHE

\begin{tabular}{ccc}
\hline $\mathbf{V}_{\text {in }}(\mathbf{m} / \mathbf{s})$ & $\mathbf{T}_{\text {in-EAHE }}\left({ }^{\mathbf{O}} \mathbf{C}\right)$ & $\varepsilon$ \\
\hline 2 & 34.76 & 0.50585 \\
3 & 35.27 & 0.48812 \\
\hline
\end{tabular}

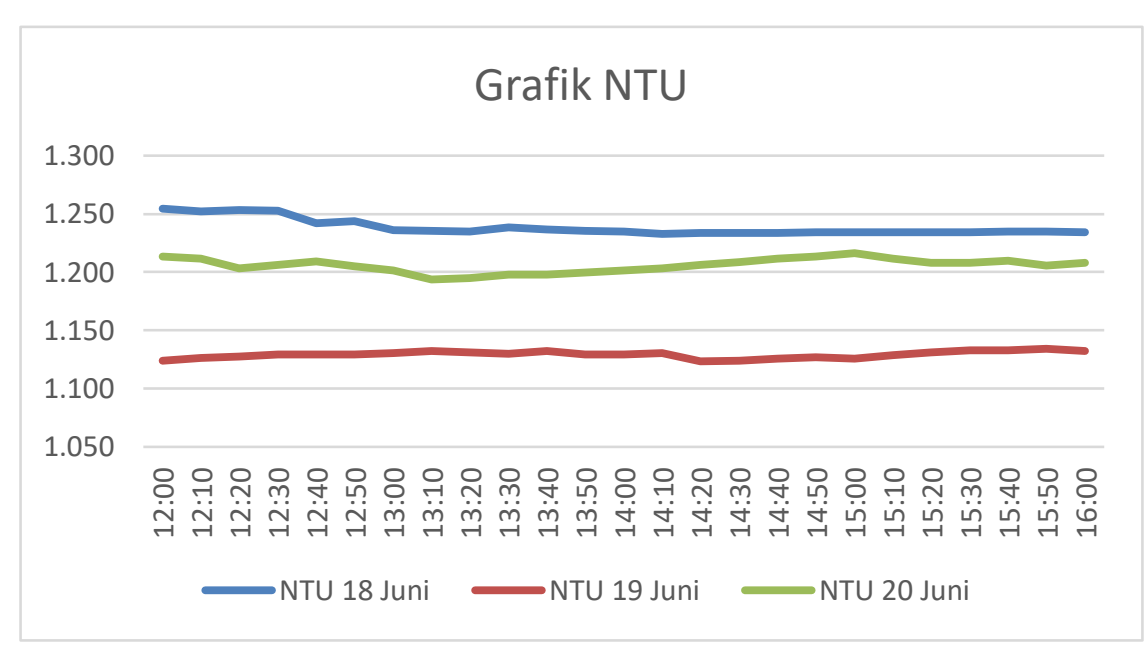

Gambar 9 Hasil perhitungan NTU Tanggal 18 Juni, 19 Juni dan 20 Juni

Gambar 9 menunjukkan perhitungan data NTU berdasarkan hasil pengambilan data pada tanggal 18 Juni 2019 sampai 20 Juni 2019. Dari Gambar grafik diatas dapat dilihat bahwa nilai NTU pada tanggal 18 Juni 2019 dengan kecepatan 2 m/s lebih tinggi dari nilai NTU pada tanggal 20 Juni 2019 dengan kecepatan $3 \mathrm{~m} / \mathrm{s}$.

\section{Kesimpulan}

Berdasarkan hasil pengujian, Air Heat Exchanger yang digunakan sebagai pendingin pasif ruangan dapat memberikan kinerja yang cukup baik. Penurunan suhu di ruangan uji dapat mencapai $3-6^{\circ} \mathrm{C}$. Pada pengujian tanggal 18 Juni 2019, NTU (Number of Transfer Unit) ratarata diperoleh sebesar 1,238 dan tertinggi sebesar 1,254 dengan kecepatan udara $2 \mathrm{~m} / \mathrm{s}$. Pada tanggal 19 Juni 2019 diperoleh nilai $N T U$ rata-rata sebesar 1,129 dan tertinggi sebesar 1,134 dengan kecepatan udara $3 \mathrm{~m} / \mathrm{s}$. Semakin tinggi kecepatan udara yang masuk untuk bersirkulasi di 
dalam Earth Air Heat Exchanger maka semakin kecil nilai NTU yang diperoleh. Dalam sistem penukar kalor tanah udara ini, nilai COP akan turun karena dipengaruhi oleh nilai NTU yang semakin menurun. Saat kecepatan udara $2 \mathrm{~m} / \mathrm{s}$ nilai NTU rata-rata 1,238 sehingga nilai COP ratarata 0,258 . Ketika kecepatan udara $3 \mathrm{~m} / \mathrm{s}$ nilai NTU rata-rata 1,129 maka nilai COP rata-rata 0,197. Hal ini terjadi akibat semakin rendahnya temperatur udara masuk pada alat penukar kalor udara-tanah. Yang menyebabkan, kapasitas kalor spesifik juga akan semakin kecil. Kondisi ini akan berpengaruh pada turunnya nilai kapasitas pendingin dari alat penukar kalor tersebut.

\section{Saran}

1. Pada proses perancangan Earth Air Heat Exchanger hendaknya EAHE jangan terlalu jauh dari ruangan uji pendinginan agar mengurangi naiknya temperatur akibat jalur untuk bersirkulasi.

2. Diperlukannya penambahan collector untuk menambah kinerja dari sistem yang dirancang.

3. Pengujian hendaknya dilakukan dengan kondisi cuaca yang cukup cerah untuk mendapatkan kinerja Earth Air Heat Exchanger yang optimal.

4. Pada Penelitian selanjutnya dapat ditambahkan beban ruangan seperti orang dan lampu untuk mendapatkan hasil penelitian yang lebih baik.

\section{Ucapan Terima Kasih}

Penulis mengucapkan terimakasih kepada Universitas Sumatera Utara atas bantuan dana yang diberikan melalui proyek penelitian TALENTA tahun 2019.

\section{Daftar Pustaka}

[1] Belatrache D. "Numerical Analysis of Earth Air Heat Exchanger at Operating Conditions in Arid Climates.2016

[2] International Journal of Hydrogen Energy. 30. 1-7.

[3] Bulut H "Experimental Analysis of An Earth Tube Ventilation System Under Hot and Dry Climatic Conditions. Proceedings of the 12nd National Sanitary Engineering Congress. vol 2. 1789-1804.2014

[4] Ben J. D "Investigation of The Ground Thermal Potential in Tunisia Focused Towards Heating and Cooling Applications. Aplied Thermal Engineering. vol. 30. 10991-1100.2010

[5] Sitorus T. B. IOP Conf. Series: Materials Science and Engineering 309, 012089, 2018.

[6] Incropera F.P "Introduction to Heat Transfer. Edisi ke 7, John Wiley \& Sons. New York. (2011)

[7] Bisiniya T.S "Design of Earth-Air Heat Exchanger System. Geothermal Energy. vol 3. 1828.

[8] Pfafferott J. (2003) "Evaluation of Earth to Air Heat Exchanger With A Standarised Method to Calculate Energy Efficiency. Energy and Buildings. Vol 35. 971-983. (2015)

[9] Vaz J. "An Experimental Study on The Use of Earth-Air Heat Exchanger. Energy and Buildings. Energy and Buildings. vol 72. 122-131. (2014)

[10] Yang D., et al., "Evaluation of The Termal Performance of An Earth to Air Heat Exchanger in a Harmonic Thermal Environtment. Energy Conversion and Management. Vol 109. 184- 
194. (2015)

[11] Been Jmaa Derbel H, Kanoum O. Investigation of the ground themal potential in Tunisia focused toward heating and cooling applications. Aplied Thermal Engineering.2010.

[12] Akhyar Wahyu Rokhadi Pengujian Karakteristik Perpindahan Panas dan Penurunan Tekanan dari Sirip-Sirip Pin Ellips Susunan Selang-Seling dalam Saluran Segiempat. 2010

[13] T Budhyastoro, Sidik Haddy Tala'ohu, dan Robert L Watung. 0000. Pengukuran Suhu Tanah. Hal. 261-262

[14] Hendrico. Rancang Bangun Alat Penukar Kalor Tabung Sepusat. Hal.5. 2015

[15] Girja Sharan,Ratan Jadhad. Performence Of Single Pass eart- Tube Heat Exchanger:An Experimental Study 